\title{
Effect of brewing material and various additives on polyphenolic composition and antioxidant bioactivity of commercial Tilia platyphyllos Scop. infusions
}

\author{
Hilal BARDAKCI ${ }^{1 *}$ (D), Timur Hakan BARAK ${ }^{1}$ (D), Kevser ÖZDEMİR 1 (D), Engin CELEP 2 (D) \\ 1 Department of Pharmacognosy, Faculty of Pharmacy, Acıbadem Mehmet Ali Aydınlar University, İstanbul, \\ Turkey. \\ 2 Department of Pharmacognosy, Faculty of Pharmacy, Yeditepe University, İstanbul, Turkey. \\ * Corresponding Author. E-mail: hilal.bardakci@acibadem.edu.tr (H.B); Tel. +90-216-500 4444.
}

Received: 25 September 2019 / Revised: 21 November 2019 / Accepted: 09 December 2019

\begin{abstract}
Herbal infusions have become very popular due to their pleasant flavor as well as their positive influence on health. The compositions of such infusions are affected by the extraction technique, duration, additives as well as container materials. This study implements comparison of antioxidant activities and phenolic contents of the infusions commercially purchased Tilia platyphyllos Scop. samples, one of the most preferred herbal infusions worldwide, prepared by using teapots with different materials. Antioxidant potencies of the samples were examined using tests with different mechanisms such as free radical scavenging test (DPPH), metal-related activity tests (CUPRAC, FRAP). On account of assessing the phenolic profile, total phenol, phenolic acid and flavonoid contents were estimated spectrophotometrically. In addition, the presence of protocatechuic acid in the extracts was investigated by HPTLC densitometry (between 0.762-1.037 w/w\%). Besides, antioxidant activities (DPPH, CUPRAC and TOAC) of the extracts were re-calculated after addition of natural/synthetic sweeteners, brown and white sugar, lemon, flower and pine honeys to the infusions. Results showed that the highest total antioxidant capacity was seen on Tiliae infusions prepared in ceramic teapot $(672.80 \pm 1.40 \mathrm{mg} \mathrm{AAE} / \mathrm{g} \mathrm{DE})$. Moreover, stevioside addition enhanced DPPH radical scavenging of Tiliae extracts $\left(2781.76 \pm 44.38 \mathrm{EC}_{50}\right.$ in $\left.\mu \mathrm{g} / \mathrm{mL}\right)$. This is the first report related with comparison of these brewing materials and additives in respect to their phenolic content and antioxidant activity of herbal teas.
\end{abstract}

KEYWORDS: Tilia platyphyllos; infusion; antioxidant activity; HPTLC; protocatechuic acid.

\section{INTRODUCTION}

Even though the antioxidants were once known only as food preservatives, it is now evidential that they inhibit the oxidation processes in human body as well as in foods [1]. Reactive oxygen species (ROS) are the intermediates generated during the normal metabolic activity, which are effectively neutralized by the antioxidant system of the human body. Any imbalance in this normal metabolism leads ROS to damage cell membranes, enzymes and DNA, which has been one of the major causes of various diseases including neurodegenerative diseases, cancer, and inflammatory condition [2]. Antioxidants are believed to prevent the damage caused by oxidative stress. They show this activity via different mechanisms like chelation of metallic ions $\left(\mathrm{Fe}^{2+}, \mathrm{Fe}^{3+}, \mathrm{Cu}^{2+}\right.$ and $\left.\mathrm{Cu}^{+}\right)$and activation of antioxidant enzymes [3].

In phytotherapy, Tiliae flowers are commonly used for numerous indications, such as for the common cold treatment, nervous tension, migraine, liver and gall bladder disorders as well as due to its expectorant, diuretic, antispasmodic, sedative, stomachic and diaphoretic activities [4-6]. European Medicines Agency published the traditional use of Tilia cordata and Tilia platyphyllos in relief of the symptoms of common cold, chronic cough and mental stress in various countries [7]. Due to its medicinal purposes and its pleasant taste, it is frequently used in Turkey as herbal tea. In the light of previous studies on composition of Tilia spp. it was determined that these species contain essential oil, mucilaginous polysaccharides, condensed tannins, procyanidin dimers, flavonoids, phenolic acids, amino acids, carbohydrates and saponins [7,8]. Besides, protocatechuic acid was already found to be the most abundant phenolic acid found in T. plathyphyllos [9].

How to cite this article: Bardakcı H, Barak TH, Özdemir K, Celep E, Effect of brewing material and various additives on polyphenolic composition and antioxidant bioactivity of commercial Tilia platyphyllos Scop. infusions. J Res Pharm. 2020; 24(1): $133-141$. 
Among them, medicinal properties of Tilia spp. have been referred to its flavonoid, volatile oil and mucilage composition [6.10].

Although various extraction/preparation techniques are present for herbal teas such as maceration, decoction, soxhlet extraction, linden tea is chosen to be prepared as infusion. In literature, there are many publications related with the bioavailability of the herbal teas and their extraction technique, extraction solvent even brewing duration while those parameters appear to influence the composition of herbal teas [11-13]. Teapot materials are as important as brewing conditions such as solvent selection and extraction duration; while they can release heavy metals into teas that people use for healing purposes [14,15]. It also brings the question if the other container materials have a role on the activities of herbal teas. Along with the extraction material, addition of flavoring substances like lemon, sugar, milk and honey also affects the bioactivity. The way of brewing tea differs among societies. People add various materials in order to give flavor and sweeten their teas. Pẹkal et al. examined the antioxidant activities of flavored black teas and stated the difference in bioactivity between flavored teas and standard black tea [16]. Sharma et al. and Toydemir et al. conducted similar studies related with the influence of milk, sugar and honey addition in various herbal teas on their antioxidant activities $[17,18]$.

This study evaluates the antioxidant activities, phenolic and protocatechuic acid contents of Tilia platyphyllos infusions prepared by using different brewing materials like copper, stainless steel, ceramic and glass pots, which are usual members of households and aluminum pots which are generally preferred by campers as well as addition of several flavors such as natural sweetener, synthetic sweetener, brown sugar, white sugar, lemon, flower honey and pine honey to the infusions, since the extraction techniques and flavoring compounds influence the phytochemical compositions and bioactivities of herbal tea compositions.

\section{RESULTS and DISCUSSION}

\subsection{Evaluation of brewing techniques and additives on herbal infusions}

There are numerous studies comparing the bioactivities and phytochemical compositions of different extracts prepared by using different methods, different infusion temperatures, multiple extraction, different brewing times [11,12,19,20]. Metal exposure is a possible undesirable result of food and beverage consumption. Boularbah et al. measured the toxicity of discharging heavy metals from the teapots [14]. According to the results, stainless steel teapot did not exhibit any toxicity from heavy metals and possibly that outcome originates for relatively small release of metals into the water. Teapots containing copper (the tin layer was missing in places) was found to be the most toxic, leading to exposure of the water to the copper alloy. Additionally, this teapot released the high amounts of $\mathrm{Zn}$ as well as $\mathrm{Cu}$. The non-toxic stainless steel teapot released very small amount of $\mathrm{Zn}(1.64 \mathrm{mg} / \mathrm{L})$. This study showed that chemical analysis of teapot leachates for heavy metals generally affirms the toxicity data provided by MetPAD, which is definite for heavy metal toxicity heavy metals. Boularbah et al. recommended stainless steel teapots, to bypass further daily metal intake, instead of those containing metal alloys, which may deliver metals during the infusion process [14]. Similarly, Petit et al. examined the lead intoxication from metallic teapots [21] and Ojezele et al. calculated the metal transfer capacity of cooking utensils [22]. Heavy metals, might cause harmful effects and cause serious health problems, especially for fetuses, infants and children due to the exposure concentration per body weight. Researches showed that the solubility of metals present in plants increases with extraction time [23]. Although high rate of metal concentration in plants is mainly caused by soil characteristics, place of harvesting, altitude, chemical fertilizer or other medicine additions, and genetic characteristics, tools using during collection, equipment used during transportation and shipping, storage conditions as well as extraction materials highly affect metal concentration [14,21,22]. Remarkably, accumulation of metal ions in plants leads formation of free radicals and stimulates the antioxidative defense systems in plants. The excess exposure to metals can damage to plant cells stimulating the free radical generation and ROS. Heavy metals influence the metabolic pathways interacting with organic compounds in the plant cell components when they enter the plant tissues. In addition, heavy metals can cause the formation of free radicals and replace essential metals [24]. During heavy metal exposure phenolic compounds act as metal chelators. Antioxidant activity of phenolic components is due to their huge tendency to chelate metals via various routes such as direct chelation, Fenton reaction etc., Furthermore, metal ions have the ability to decompose lipid hydroperoxide (LOOH) and result in lipid alkoxyl radicals, which trigger free radical chain oxidation. Phenolic antioxidants similarly can inhibit lipid peroxidation by trapping the lipid alkoxyl radical [25]. 


\subsection{Assessment of polyphenolic composition of linden infusions}

European Medicines Agency announced the traditional use of Tilia cordata and Tilia platyphyllos prepared in boiling water as herbal infusions in relief of the symptoms of common cold, chronic coughing and mental stress in various countries [7]. In Europe, herbal teas containing Tiliae flowers are recommended for common cold. Although people use Tiliae flowers as an infusion prepared by boiled water, there are many studies investigating the biological activities of Tiliae flowers by using different extraction techniques and materials. Karioti et al. compared the phytochemical composition of decoction, infusion, tinctures and alcoholic extracts of Tiliae samples [10]. Majer et al. examined the antioxidant activities of Tiliae flowers with different sunlight exposures [26]. Cittan et al. compared the antioxidant activity and phenolic content of Tilia cordata fruit samples prepared by ultrasound-assisted extraction and infusion [27]. According to the results, ultrasound-assisted extraction technique with methanol was considered to have higher effect then traditional water infusion. Moreover, protocatechuic acid was determined to be the major phenolic compound in both extracts.

In the light of previous studies, infusions of Tiliae samples by using different type of teapot materials: glass, ceramic, stainless steel, copper and aluminum were prepared. Antioxidant activity, phenolic contents and protocatechuic acid contents of whole extracts were measured. Antioxidant activity and phenolic content results were shown in Tables 1-3. The infusion prepared by ceramic pot showed the highest total phenolic content $(672.80 \pm 1.81)$, total phenolic acid content $(61.16 \pm 2.50)$, total flavonoid content $(17.64 \pm 1.2)$, DPPH radical scavenging $\left(\mathrm{EC}_{50} 636.35 \pm 23.05 \mu \mathrm{g} / \mathrm{mL}\right)$, FRAP activity $(1.64 \pm 0.04)$, CUPRAC activity (791.27 \pm 2.96$)$ and TOAC $(672.00 \pm 1.40)$ whereas not the highest protocatechuic acid content $(0.762 \%)$.

Table 1. Spectrophotometric determination of phenolic profile of TP infusions.

\begin{tabular}{lccccc}
\hline Analysis & Aluminum & Ceramic & Copper & Glass & Stainless steel \\
\hline Total phenolic content $^{\mathrm{A}}$ & $521.33 \pm 1.30^{\mathrm{a}}$ & $672.80 \pm 1.81^{\mathrm{b}}$ & $566.40 \pm 1.99^{\mathrm{c}}$ & $511.93 \pm 1.87^{\mathrm{d}}$ & $514.46 \pm 1.66^{\mathrm{d}}$ \\
Total flavonoid content $^{\mathrm{B}}$ & $9.32 \pm 0.26^{\mathrm{a}}$ & $17.64 \pm 1.24^{\mathrm{b}}$ & $12.85 \pm 0.30^{\mathrm{c}}$ & $9.29 \pm 0.97 \mathrm{a}$ & $8.52 \pm 0.46^{\mathrm{a}}$ \\
Total phenolic acid content $^{\mathrm{C}}$ & $25.23 \pm 1.16^{\mathrm{a}}$ & $61.16 \pm 2.50^{\mathrm{b}}$ & $49.53 \pm 2.82^{\mathrm{c}}$ & $35.26 \pm 3.81^{\mathrm{d}}$ & $32.5 \pm 1.77^{\mathrm{d}}$ \\
\hline
\end{tabular}

A Results were expressed as the mean of triplicates \pm standard deviation (S.D.) and as mg gallic acid equivalents (GAE) in $1 \mathrm{~g}$ sample.

B Results were expressed as the mean of triplicates \pm standard deviation (S.D.) and as mg quercetin equivalents (QE) in 1 g sample.

C Results were expressed as the mean of triplicates \pm standard deviation (S.D.) and as mg caffeic acid equivalents (CAE) in $1 \mathrm{~g}$ sample.

a-e Different letters in the same row indicate significance $(\mathrm{p}<0.05)$.

Table 2. Quantification data for protocatechuic acid content of TP infusions.

\begin{tabular}{lllllllllll}
\hline $\begin{array}{l}\text { Compound/ } \\
\text { Infusion }\end{array}$ & Aluminum & $\begin{array}{l}\mathrm{CV} \\
\%\end{array}$ & Ceramic & $\begin{array}{l}\mathrm{CV} \\
\%\end{array}$ & Copper & $\begin{array}{l}\mathrm{CV} \\
\%\end{array}$ & Glass & $\begin{array}{l}\mathrm{CV} \\
\%\end{array}$ & $\begin{array}{l}\text { Stainless } \\
\text { steel }\end{array}$ & $\begin{array}{l}\mathrm{CV} \\
\%\end{array}$ \\
\hline $\begin{array}{l}\text { Protocatechuic } \\
\text { acid (w/w\%) }\end{array}$ & 0.905 & 1.66 & 0.762 & 3.04 & 1.037 & $\begin{array}{l}0.8 \\
2\end{array}$ & 0.858 & 3.02 & 0.875 & 2.70 \\
\hline
\end{tabular}

${ }^{*} \mathrm{CV}$ : Coefficient of Variation

Contrary to expectations, the infusion prepared in glass pot showed lower activity in general even lowest CUPRAC $(702.57 \pm 13.85)$ and TOAC $(511.93 \pm 1.22)$ activities. As assumed infusions prepared in aluminum pot showed lowest TPC (521.33 \pm 1.30$)$, TPA (25.23 \pm 1.16$)$, DPPH radical scavenging (EC 50 $741.09 \pm 25.81 \mu \mathrm{g} / \mathrm{mL})$ and FRAP $(0.97 \pm 0.05)$ activity. From these results, it can be interpreted that, along with the phenolic, volatile composition of T. platyphyllos have contributed the antoxidant activity of the extracts.

Flavoring compounds comparably affect the composition and bioactivity of herbal teas as well. According to Stahl et al., milk addition to black tea lowered the antioxidant activity [28]. Sugar addition was also lowered the DPPH scavenging activity when compared with the standard black tea. Toydemir et al. examined the antioxidant activities of flower and pine honey added various herbal teas [18]. In respect to linden, TPC, total flavonoid content, TOAC and CUPRAC values were greater with addition of honey. The 
antioxidant activity and the phenolic composition were greater in linden samples added with stevioside a natural diterpenoid compound which is used as sweetener.

Table 3. In vitro antioxidant activities of TP infusions.

\begin{tabular}{llllll}
\hline Analysis & Aluminum & Ceramic & Copper & Glass & Stainless steel \\
\hline DPPH scavenging activity $^{\mathrm{A}}$ & $741.09 \pm 25.81^{\mathrm{a}}$ & $636.35 \pm 23.05^{\mathrm{b}}$ & $677.79 \pm 51.61^{\mathrm{ab}}$ & $682.84 \pm 8.05^{\mathrm{ab}}$ & $717.70 \pm 32.41^{\mathrm{ab}}$ \\
FRAPB $^{\mathrm{a}}$ & $0.97 \pm 0.05^{\mathrm{a}}$ & $1.64 \pm 0.04^{\mathrm{b}}$ & $1.27 \pm 0.07^{\mathrm{c}}$ & $1.01 \pm 0.01^{\mathrm{a}}$ & $1.05 \pm 0.05^{\mathrm{a}}$ \\
CUPRACC $^{\text {Total antioxidant capacity }}$ & $716.95 \pm 51.78^{\mathrm{ab}}$ & $791.27 \pm 2.96^{\mathrm{a}}$ & $733.22 \pm 17.78^{\mathrm{ab}}$ & $702.57 \pm 13.85^{\mathrm{b}}$ & $745.21 \pm 34.71^{\mathrm{ab}}$ \\
& $521.33 \pm 1.22^{\mathrm{a}}$ & $672.80 \pm 1.40^{\mathrm{b}}$ & $566.40 \pm 1.44^{\mathrm{c}}$ & $511.93 \pm 1.22^{\mathrm{d}}$ & $514.46 \pm 1.41^{\mathrm{e}}$ \\
\hline
\end{tabular}

P.S. 1) $\mathrm{EC}_{50}$ value of the reference compound "BHT" in DPPH scavenging activity is found to be $390.18 \pm 4.86 \mu \mathrm{g} / \mathrm{mL} .2$ ) FRAP activity of the reference compound "BHT" is found to be $4.07 \pm 0.52 \mathrm{mM} \mathrm{FeSO} 4$ eq. in $1 \mathrm{~g}$ sample.

A Results were expressed as the mean of triplicates \pm standard deviation (S.D.) and DPPH activity was expressed as EC 50 in $\mu \mathrm{g} / \mathrm{mL}$ equivalents.

В Results were expressed as the mean of triplicates \pm standard deviation (S.D.) and as $\mathrm{Mm} \mathrm{FeSO}_{4}$ equivalents in $1 \mathrm{~g}$ sample.

C Results were expressed as the mean of triplicates \pm standard deviation (S.D.) and as $\mathrm{mg}$ ascorbic acid equivalents (AAE) in $1 \mathrm{~g}$ sample.

a-e Different letters in the same row indicate significance $(\mathrm{p}<0.05)$.

Korir et al. studied alterations on antioxidant activity of tea samples after addition of some additives such as stevia, honey and sugar [29]. Results indicated that stevia addition produced no significant modification on antioxidant activity. In contrary sugar and honey inclusion expressively decreased the antioxidant activity. As a result, stevia was determined as preferable sweetener for obtaining severe antioxidant activity. In another study, honey addition to several fruit tea infusions was reduced total phenolic content and antioxidant activity by $28 \%$ and $22 \%$ respectively. It may be hypothesized that glycosylation causes reduction on hydrogen donation of polyphenols therefor sugar and honey addition impairs antioxidant activity [30]. Lemon is rich for sugar and ascorbic acid. Even though sugar has negative effect for antioxidant activity, ascorbic acid is known efficient antioxidant substance. Our results revealed that stevia and synthetic sweetener added samples have significantly higher antioxidant activities when compared to sugar and honey added samples (Table 4). These results are expectable in the light of previous studies. Lemon added samples have mild antioxidant activity however significantly higher than sugar and honey added samples. It may be claimed that ascorbic acid compensated negative effects of sugars of lemon and resulted with nothing but mild decrease when compared to honey and sugar.

Table 4. In vitro antioxidant activities of TP infusions with various flavors.

\begin{tabular}{lccccccc}
\hline Analysis & Stevioside & $\begin{array}{c}\text { Synthetic } \\
\text { sweetener }\end{array}$ & $\begin{array}{c}\text { Brown } \\
\text { Sugar }\end{array}$ & White Sugar & $\begin{array}{c}\text { Flower } \\
\text { Honey }\end{array}$ & $\begin{array}{c}\text { Pine } \\
\text { Honey }\end{array}$ & Lemon \\
\hline $\begin{array}{l}\text { DPPH } \\
\text { scavenging }\end{array}$ & 2781.76 & 3412.50 & 6793.99 & 8873.36 & 7425.16 & 11675 & 4487.41 \\
activity $^{\mathrm{A}}$ & $\pm 44.38^{\mathrm{a}}$ & $\pm 98.66^{\mathrm{b}}$ & $\pm 81.80^{\mathrm{a}}$ & $\pm 410.81^{\mathrm{c}}$ & $\pm 308.07^{\mathrm{a}}$ & $\pm 299.27^{\mathrm{d}}$ & $\pm 112.44^{\mathrm{e}}$ \\
CUPRACC & 192.78 & 157.03 & 19.11 & 15.15 & 17.03 & 11.30 & 55.19 \\
& $\pm 9.39^{\mathrm{a}}$ & $\pm 8.91^{\mathrm{b}}$ & $\pm 0.82^{\mathrm{c}}$ & $\pm 0.59^{\mathrm{c}}$ & $\pm 0.76^{\mathrm{c}}$ & $\pm 0.61^{\mathrm{c}}$ & $\pm 0.59^{\mathrm{d}}$ \\
$\begin{array}{l}\text { Total } \\
\begin{array}{l}\text { antioxidant } \\
\text { capacity }\end{array}\end{array}$ & 111.22 & 95.71 & 55.23 & 41.33 & 49.20 & 45.97 & 55.84 \\
\hline
\end{tabular}

P.S. 1) $\mathrm{EC}_{50}$ value of the reference compound "BHT" in DPPH scavenging activity is found to be $390.18 \pm 4.86 \mu \mathrm{g} / \mathrm{mL} .2$ ) FRAP activity of the reference compound "BHT" is found to be $4.07 \pm 0.52 \mathrm{mM} \mathrm{FeSO} 4$ eq. in $1 \mathrm{~g}$ sample.

A Results were expressed as the mean of triplicates \pm standard deviation (S.D.) and DPPH activity was expressed as EC50 in $\mu \mathrm{g} / \mathrm{mL}$ equivalents.

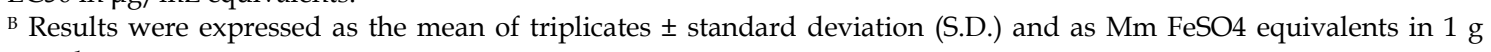
sample.

C Results were expressed as the mean of triplicates \pm standard deviation (S.D.) and as $\mathrm{mg}$ ascorbic acid equivalents (AAE) in $1 \mathrm{~g}$ sample.

a-e Different letters in the same row indicate significance $(p<0.05)$. 


\section{CONCLUSION}

In the light of the information obtained from this study, it is designated that, the brewing materials during the preparation of the herbal teas and additives are also very important to their effects and therapeutically usages. Consequently, the preparation methods and additives of the herbal teas have to be chosen according to the aim of disease treatment.

\section{MATERIALS AND METHODS}

\subsection{Chemicals and reagents}

All of the chemicals, and references used during the experiments were purchased from Sigma Chemical Co. (St. Louis, MO, USA). Spectrophotometric calculations were conducted using Thermo Multiskan Sky Microplate Spectrophotometer. Protocatechuic acid contents were measured by CamagHPTLC system.

\subsection{Plant materials}

The commercially available Tilia platyphyllos (TP) samples were purchased from the local market in Istanbul/Turkey. The classification of the commercial plant material was performed using "Flora of Turkey and the East Aegean Islands" [31].

\subsection{Preparation of brews}

The infusions were prepared from $2 \mathrm{~g}$ plant materials which contains equal amounts of bracteols and flowers, with $100 \mathrm{~mL}$ of freshly boiled water representing the ordinary quantity consumed by tea drinkers, in pots which are made of glass, ceramic, stainless steel, copper and aluminum, for 5 minutes with a closed cap; filtered by using filter paper. $0.5 \mathrm{~g}$ natural sweetener (stevioside), and synthetic sweetener (aspartame), $5 \mathrm{~g}$ brown and white sugar, $5 \mathrm{~g}$ flower and pine honey, and $10 \mathrm{~mL}$ of lemon juice were added on freshly prepared ceramic pot infusions, separately. The amounts of the additives were calculated by observing the packages sold for one cup of tea.

\subsection{Quantitative assessment of polyphenolic content}

\subsubsection{Total phenolic content}

The evaluation of total phenolic contents of the infusions was executed according to the method described by Singleton and Rossi [32]. Diluted infusion samples were introduced into the blend of $\mathrm{Na}_{2} \mathrm{CO}_{3}$ (20\%) and FCR (Folin-Ciocalteu reagent which diluted with $\mathrm{H}_{2} \mathrm{O}(1: 9)$ ). Thereafter the incubation duration at $45^{\circ} \mathrm{C}$ for $30 \mathrm{~min}$., the absorbance of the mixtures was calculated at $765 \mathrm{~nm}$. The results were expressed as gallic acid equivalents (GAE) per g dry extract (DE).

\subsubsection{Total flavonoid content}

Total flavonoid contents of the infusions were determined via the method described by Celep et al. [33] . Diluted specimens were blended with the admixture of Aluminum chloride (10\%) and sodium acetate $(1 \mathrm{M})$, and the incubation process lasted for $30 \mathrm{~min}$ at room temperature. The absorbance was read at $415 \mathrm{~nm}$. Total flavonoid content was given as mg quercetin equivalents $(\mathrm{QE})$ per $\mathrm{g}$ dry extract.

\subsubsection{Total phenolic acid content}

The total phenolic acid content of the infusions was spectrophotometrically measured at $490 \mathrm{~nm}$ [34]. The method is based on forming a complex due to the chemical reaction of sodium molybdate-sodium nitrite with phenolic acids. The results were assessed as caffeic acid equivalents (CAE) in per g dry extract.

\subsection{HPTLC quantification of protocatechuic acid}

Protocatechuic acid contents of the Tiliae infusions were calculated by a method published recently by Niranjan et al. [35]. The concentration of standard solution of protocatechuic acid $(250 \mu \mathrm{g} / \mathrm{mL})$ was adjusted in methanol and $5 \mathrm{mg}$ of total extract and each fraction were dissolved in $1 \mathrm{~mL}$ methanol. $0.45 \mu \mathrm{m}$ syringe filter was used for filtration of extracts. $15 \mu \mathrm{L}$ of Tiliae samples were applied in triplicate. Application of $2 \mu \mathrm{L}$ to $5.5 \mu \mathrm{L}$ of standard protocatechuic acid solution was in triplicate. Band length of the standard solutions and samples was $8 \mathrm{~mm}$ on silica gel glass HPTLC plates $60 \mathrm{~F}_{254}$ with Camag Automatic TLC Sampler IV. The mobile phase was toluene:ethyl acetate:formic acid (14:10:1) (v/v/v). Developments were executed in 
Camag Automatic Developing Chamber (ADC-2). Saturation process of the chamber lasted 20 min before the development. The humidity control managed by $\mathrm{ADC}-2$ via using $\mathrm{MgCl}_{2}$ (33\% $\mathrm{RH}$ ) for 10 minutes. Densitometric screening was implemented by using Camag TLC Scanner IV at $282 \mathrm{~nm}$ and VisionCATS software in fluorescence mode after development of $70 \mathrm{~mm}$. The slit dimension was arranged as $5 \times 0.2 \mathrm{~mm}$, micro and the scanning speed was $20 \mathrm{~mm} / \mathrm{s}$. Amounts of standards in the extracts were obtained by comparison of AUCs with the standards' calibration curve $\left(y=1.742^{*} 10^{-8} x-4.159^{*} 10^{-3}\right)$. The coefficient variation coefficient $(\mathrm{CV} \%)$ was $1.62 \%$ and the correlation coefficient $(\mathrm{R})$ of the calibration curve was more than 0.998 . The presence of standard compounds in extracts was ensured by comparison of the retention factors (Rf 0.550) and overlapping UV spectra of each extract and standards (Figures 1-2).

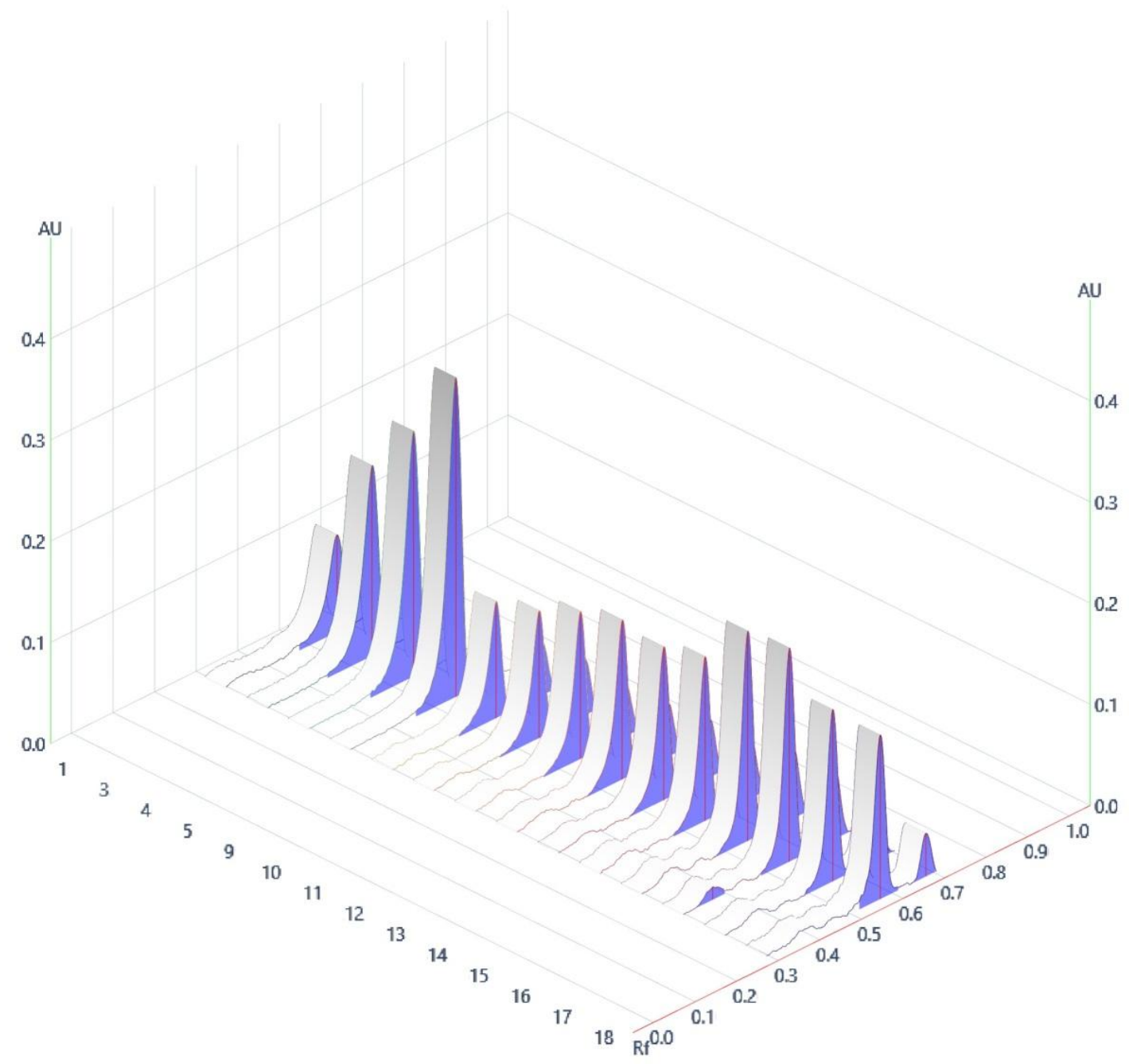

Figure 1. Separation and $\mathrm{R} f$ value of protocatechuic acid standard and Tiliae infusions prepared in different brewing materials.

\subsection{Assessment of antioxidant activity based on DPPH radical-scavenging activity}

Scavenging activity of DPPH radical was determined using the method stated earlier by Celep et al. [36]. Dilution of specimens were performed freshly and separately mixed with $100 \mu \mathrm{M}$ methanolic DPPH solution. The mixtures were maintained at room temperature and at the dark for $50 \mathrm{~min}$., and the calculation of the absorbance conducted at $517 \mathrm{~nm}$. $\mathrm{EC}_{50}$ values of the infusions were calculated by using five different concentratons. Butylated hydroxytoluene (BHT) was selected as reference compound. 


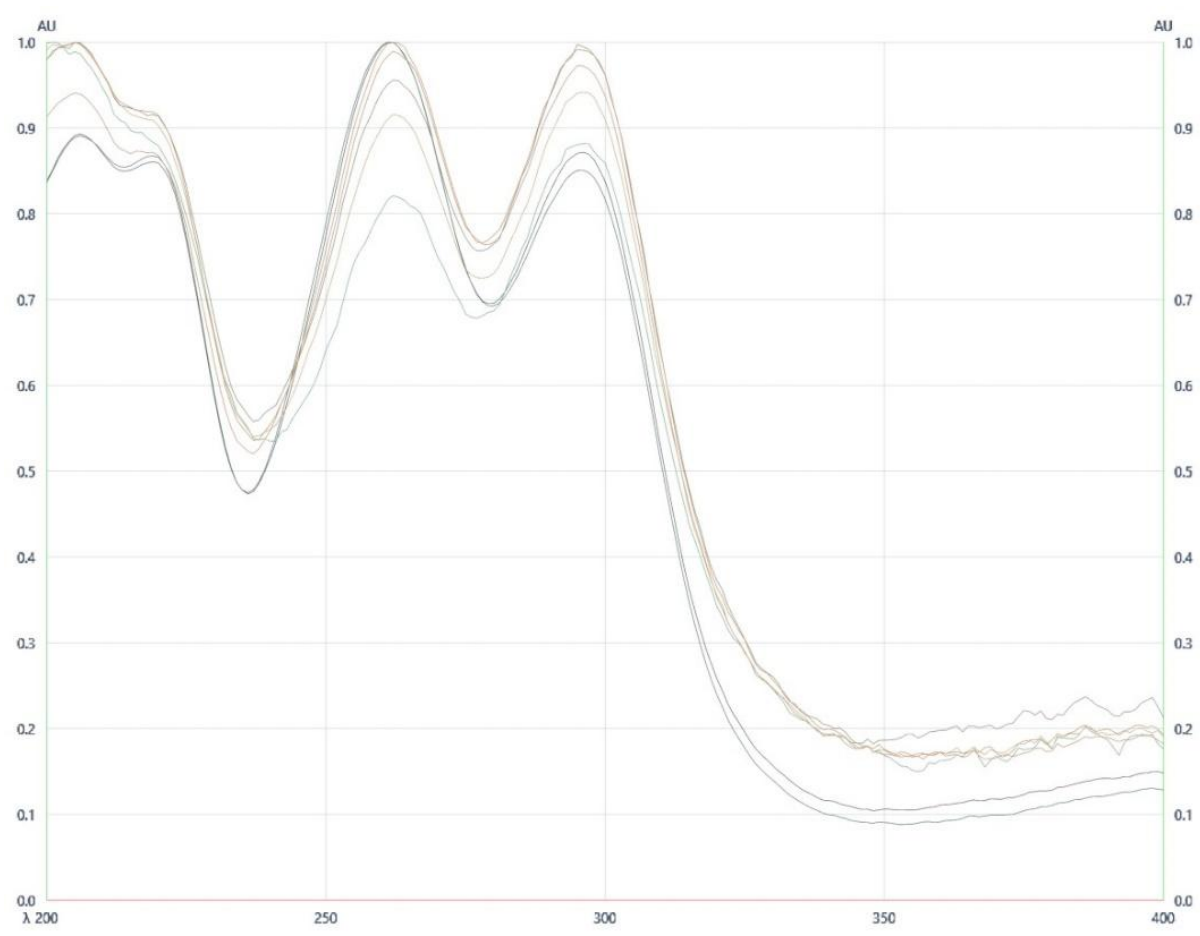

Figure 2. Overlapped UV spectra of protocatechuic acid standard and Tiliae infusions prepared in different brewing materials at $282 \mathrm{~nm}$.

\subsection{Assessment of antioxidant activity based on metal-reduction potential}

\subsubsection{Cupric reducing antioxidant capacity (CUPRAC)}

CUPRAC activities of the studied samples were determined using the modified method of Apak et al. [37]. Exact same volumes of Copper sulfate $(10 \mathrm{mM})$, ammonium acetate buffer $(1 \mathrm{M}, \mathrm{pH} 7.0)$ and neocuproine $(7.5 \mathrm{mM})$ were mixed, independently. Afterwards, infusions were added to the mixture and then incubation process lasted for $1 \mathrm{~h}$, and the absorbance was recorded at $450 \mathrm{~nm}$. The results were expressed as mg ascorbic acid equivalent (AAE) per g dry extracts.

\subsubsection{Ferric reducing antioxidant power (FRAP)}

Benzie and Strain's previously described spectrophotometric method was preferred [38]. Samples were legitimately and then blended with FRAP reagent, which is composed of acetate buffer $(0.3 \mathrm{M}), 2,4,6$ tripyridyl-S-triazine $(10 \mathrm{mM})$ and $\mathrm{FeCl}_{3}(20 \mathrm{mM})$. Subsequent to $30 \mathrm{~min}$. incubation, the absorbance was measured at $593 \mathrm{~nm}$. BHT was chosen as reference compound. The results were measured as $\mathrm{mM} \mathrm{FeSO}_{4}$ per g dry extract.

\subsubsection{Estimation of total antioxidant capacity by phosphomolybdenum method}

The spectrophotometric method of Prieto et al. was carried out for the estimation of total antioxidant capacity [39]. Solutions of samples were transfused into the mixture, which consists of sodium phosphate monobasic $(28 \mathrm{mM})$, sulfuric acid $(0.6 \mathrm{M})$ and ammonium molybdate $(4 \mathrm{mM})$, for reaction. Afterwards incubation occurred for $90 \mathrm{~min}$. at $95{ }^{\circ} \mathrm{C}$, and subsequent to cooling to room temperature absorbance was read $695 \mathrm{~nm}$. Total antioxidant capacity was expressed as mg AAE per g dry extract.

\subsection{Statistics}

All of the assays and analyses were performed in triplicate. Mean \pm standard deviations were calculated in each assay. ANOVA test was used for statistical comparison of the results. The multiple comparisons were accomplished by Tukey-Kramer post hoc test. Statistically significant difference was defined as $\mathrm{p}<0.05$. 
Acknowledgements: The authors want to thank Acıbadem University Faculty of Pharmacy student Zehranur Irmak for her kind help during the experiments.

Author contributions: Concept - H.B.; Design - H.B.; Supervision - E.C.; Resources - H.B., E.C.; Materials - H.B.; Data Collection and/or Processing - H.B., T.H.B., K.Ö.; Analysis and/or Interpretation - H.B., T.H.B., K.Ö., E.C.; Literature Search - H.B., T.H.B., KÖ.; Writing - H.B., T.H.B.; Critical Reviews - H.B., T.H.B., E.C., K.Ö.

Conflict of interest statement: The authors declared no conflict of interest.

\section{REFERENCES}

[1] Cömert ED, Gökmen V. Evolution of food antioxidants as a core topic of food science for a century. Food Res Int. 2018; 105: 76-93. [CrossRef]

[2] Sarangarajan R, Meera S, Rukkumani R, Sankar P, Anuradha G. Antioxidants: Friend or foe? Asian Pac J Trop Med 2017; 10(12): 1111-1116. [CrossRef]

[3] Carocho M, Morales P, Ferreira ICFR. Antioxidants: Reviewing the chemistry, food applications, legislation and role as preservatives. Trends Food Sci Technol. 2018; 71: 107-120. [CrossRef]

[4] Baytop, T. Therapy with medicinal plants in Turkey (Past and Present) (2nd ed.). Publications of the İstanbul University, İstanbul, 1984, pp.230-231.

[5] Newall CA, Anderson LA, Phillipson JD. Herbal Medicines: A Guide for Health-care Professionals. The Pharmaceutical Press, London, 1996, pp.181-182.

[6] Toker G, Aslan M, Yeşilada E, Memişoğlu M, Ito S. Comparative evaluation of the flavonoid content in officinal Tiliae flos and Turkish lime species for quality assessment. J Pharm Biomed Anal. 2001; 26(1): 111-121. [CrossRef]

[7] European Medicines Agency, Committee on Herbal Medicinal Products, EMA/HMPC/337067/2011

[8] Yayalaci Y, Celik I, Bati B. Hepatoprotective and antioxidant activity of linden (Tilia platyphyllos L.) infusion against ethanol-induced oxidative stress in rats. J Membr Bio. 2014; 247(2): 181-188. [CrossRef]

[9] Jabeur I, Martins N, Barros L, Calhelha RC, Vaz J, Achour L, Santos-Buelga C, Ferreira ICFR. Contribution of phenolic composition to the antioxidant, anti-inflammatory, antitumor potential of Equisetum giganteum L. and Tilia plathylphyllos Scop. Food Funct. 2017; 8: 975-984. [CrossRef]

[10] Karioti A, Chiarabini L, Alachkar A, Fawaz Chehna M, Vincieri FF, Bilia AR. HPLC-DAD and HPLC-ESI-MS analyses of Tiliae flos and its preparations. J Pharm Biomed Anal. 2014; 100: 205-214. [CrossRef]

[11] Guimarães R, Barros L, Dueñas M., Calhelha RC, Carvalho AM, Santos-Buelga C, Queiroz MJ, Ferreira ICFR. Infusion and decoction of wild German chamomile: Bioactivity and characterization of organic acids and phenolic compounds. Food Chem. 2013; 136(2): 947-954. [CrossRef]

[12] Ludwig IA, Sanchez L, Caemmerer B, Kroh LW, De Peña MP, Cid C. Extraction of coffee antioxidants: Impact of brewing time and method. Food Res Int. 2012; 48(1): 57-64. [CrossRef]

[13] Nikniaz Z, Mahdavi R, Ghaemmaghami SJ, Lotfi Yagin N, Nikniaz L. Effect of different brewing times on antioxidant activity and polyphenol content of loosely packed and bagged black teas (Camellia sinensis L.). Avicenna J Phytomed. 2016; 6(3): 313-321.

[14] Boularbah A, Bitton G, Morel JL. Assessment of metal content and toxicity of leachates from teapots. Sci Total Environ. 1999; 227(1): 69-72. [CrossRef]

[15] Ni L, Li S. Effects of organic matters coming from Chinese tea on soluble copper release from copper teapot. Sci Total Environ. 2008; 389(1): 202-207. [CrossRef]

[16] Pẹkal A, Drózdz P, Biesaga M, Pyrzynska K. Evaluation of the antioxidant properties of fruit and flavoured black teas. Eur J Nutri. 2011; 50(8): 681-688. [CrossRef]

[17] Sharma V, Vijay Kumar H, Jagan Mohan Rao L. Influence of milk and sugar on antioxidant potential of black tea. Food Res Int. 2008; 41(2): 124-129. [CrossRef]

[18] Toydemir G, Capanoglu E, Kamiloglu S, Firatligil-Durmus E, Sunay AE, Samanci T, Boyacioglu D. Effects of honey addition on antioxidative properties of different herbal teas. Pol J Food Nutri Sci. 2015; 65(2): 127-135. [CrossRef]

[19] Ariffin F, Heong Chew S, Bhupinder K, Karim AA, Huda N. Antioxidant capacity and phenolic composition of fermented Centella asiatica herbal teas. J Sci Food Agric. 2011; 91(15): 2731-2739. [CrossRef] 
[20] Dias MI, Barros L, Dueñas M, Pereira E, Carvalho AM, Alves RC, Oliveira B, Santos-Buelga C, Ferreira ICFR. Chemical composition of wild and commercial Achillea millefolium L. and bioactivity of the methanolic extract, infusion and decoction. Food Chem. 2013; 141(4): 4152-4160. [CrossRef]

[21] Petit D, Claeys F, Sykes C, Noefnet Y. Lead poisoning from metallic teapots traditionally used by North African populations. J Phys IV. 2003; 107: 1053-1056. [CrossRef]

[22] Ojezele OJ, Ojezele MO, Adeosun AM. Cooking utensils as probable source of heavy metal toxicity. Middle East J Sci Res. 2016; 24(7): 2216-2220. [CrossRef]

[23] Polat M, Ogut S. Heavy metals in some medicinal plants sold in herbal shops. Fresenius Environ Bull. 2018; 27(4): 1999-2002.

[24] Kisa D. The responses of antioxidant system against the heavy metal-induced stress in tomato. Süleyman Demirel University-J Natur App Sci. 2017; 22(1): 1. [CrossRef]

[25] Michalak A. Phenolic compounds and their antioxidant activity in plants growing under heavy metal stress. Pol J Environ Stud. 2006; 15(4): 523-530.

[26] Majer P, Neugart S, Krumbein A, Schreiner M, Hideg É. Singlet oxygen scavenging by leaf flavonoids contributes to sunlight acclimation in Tilia platyphyllos. Environ Exp Bot. 2014; 100: 1-9 [CrossRef]

[27] Cittan M, Altuntaş E, Çelik A. Evaluation of antioxidant capacities and phenolic profiles in Tilia35 cordata fruit extracts: A comparative study to determine the efficiency of traditional hot water infusion method. Ind Crop Prod. 2018; 122: 553-558. [CrossRef]

[28] Stahl T, Falk S, Rohrbeck A, Georgii S, Herzog C, Wiegand A, Hotz S, Boschek B, Zorn H, Brunn H. Migration of aluminum from food contact materials to food -a health risk for consumers? Part I of III: exposure to aluminum, release of aluminum, tolerable weekly intake (TWI), toxicological effects of aluminum, study design, and methods. Environ Sci Eur. 2017;29(1):19. [CrossRef]

[29] Korir MW, Wachira FN, Wanyoko JK, Ngure RM, Khalid R. The fortification of tea with sweeteners and milk and its effect on in vitro antioxidant potential of tea product and glutathione levels in an animal model. Food Chem. 2014; 145: 145-153. [CrossRef]

[30] Belščak A, Bukovac N, Piljac-žegarac J. The influence of ascorbic acid and honey addition on the anti-oxidant properties of fruit tea infusions: Antioxidants in fruit tea infusions. J Food Biochem. 2009; 35(1): 195-212. [CrossRef]

[31] Davis PH, Flora of Turkey and the East Aegean Islands, sixth ed., Edinburgh University Press, Edinburgh, United Kingdom, 1979, pp.633-635.

[32] Singleton VL, Rossi JA. Colorimetry of total phenolics with phosphomolybdic-phosphotungstic acid reagents. Am J Enol Vitic. 1965; 16: 144-158.

[33] Celep E, Aydın A, Kırmızıbekmez H, Yesilada E. Appraisal of in vitro and in vivo antioxidant activity potential of cornelian cherry leaves. Food Chem Toxicol. 2013; 62: 448-455. [CrossRef]

[34] Barak TH, Celep E, Inan Y, Yeşilada E. Influence of in vitro human digestion on the bioavailability of phenolic content and antioxidant activity of Viburnum opulus L. (European cranberry) fruit extracts. Ind Crop Prod. 2019; 131: 62-69. [CrossRef]

[35] Niranjan A, Ngpoore NK, Anis N, Kumar A, Lehri A, Shirke PA, Tewari SK. Simultaneous quantification of six phenolic compounds in various parts of Moringa oleifera Lam. using high-performance thin-layer chromatography. JPC-J Planar Chromat. 2017; 30(6): 502-509. [CrossRef]

[36] Celep E, Aydin A, Yesilada E. A comparative study on the in vitro antioxidant potentials of three edible fruits: Cornelian cherry, Japanese persimmon and cherry laurel. Food Chem Toxicol. 2012; 50(9): 3329-3335. [CrossRef]

[37] Apak R, Güçlü K, Özyürek M, Karademir SE. Novel total antioxidant capacity index for dietary polyphenols and vitamins $\mathrm{C}$ and $\mathrm{E}$, using their cupric ion reducing capability in the presence of neocuproine: CUPRAC method. J Agric Food Chem. 2004; 52(26): 7970-7981. [CrossRef]

[38] Benzie IF, Strain JJ. The ferric reducing ability of plasma (FRAP) as a measure of "antioxidant power": The FRAP assay. Anal Biochem. 1996; 239(1): 70-76. [CrossRef]

[39] Prieto P, Pineda M, Aguilar M. Spectrophotometric quantitation of antioxidant capacity through the formation of a phosphomolybdenum complex: Specific application to the determination of vitamin E. Anal Biochem. 1999; 269(2): 337-341. [CrossRef] 